\title{
PENGARUH IMPLEMENTASI MANAJEMEN BERBASIS MADRASAH TERHADAP KEDISIPLINAN GURU DI MIN KOTA BANDAR LAMPUNG
}

\author{
Erjati Abas \\ An Nur Lampung \\ erjati59@yahoo.co.id
}

\begin{abstract}
The purpose of this study was to determine and analyze the effect of the implementation of Madrasah-Based Management on the discipline of teachers in MIN Kota Bandar Lampung. The method used is quantitative which aims to test hypotheses using statistical techniques. The data collection technique used is a questionnaire. The sample in this study amounted to 26 teachers in MIN City of Bandar Lampung. While the data analysis technique uses simple correlation statistical tests. The results of the research are that the better the implementation of Madrasah-Based Management will increase the discipline of Islamic Education teachers in MIN Bandar Lampung City. The strength of the influence of the implementation of Madrasah-Based Management on the discipline of Islamic Education teachers in MIN City of Bandar Lampung is 0.690 which is categorized as having moderate / moderate influence.
\end{abstract}

Key words: Madrasah-Based Management, Teacher Discipline

\begin{abstract}
Abstrak
Tujuan penelitian ini adalah untuk mengetahui dan menganalisis pengaruh implementasi Manajemen Berbasis Madrasah terhadap kedisiplinan guru di MIN Kota Bandar Lampung.Metode yang digunakan adalah kuantitatif yang bertujuan menguji hipotesis dengan menggunakan teknik statistik. Teknik pengumpul data yang digunakan adalah kuesioner (angket). Sampel dalam penelitian ini berjumlah 26 orang guru di MIN Kota Bandar Lampung. Sedangkan teknik analisis data dengan menggunakan uji statistik korelasi sederhana.Hasil penelitiannya adalah semakin baik implementasi Manajemen Berbasis Madrasah maka akan semakin meningkat kedisiplinan guru Pendidikan Agama Islam di MIN Kota Bandar Lampung. Kekuatan pengaruh implementasi Manajemen Berbasis Madrasah terhadap kedisiplinan guru Pendidikan Agama Islam di MIN Kota Bandar Lampung sebesar 0,690 yang dikategorikan pengaruhnya cukup/sedang.
\end{abstract}

Kata Kunci: Manajemen Berbasis Madrasah, Kedisiplinan Guru

\section{Pendahuluan}

Mutu suatu pendidikan harus diupayakan untuk mencapai kemajuan yang dilandasi dengan suatu perubahan yang terencana. Berarti pencapaian mutu pendidikan tidak terjadi dengan sendirinya dan tiba-tiba aka $\mathrm{n}$ tetapi perlu adanya suatu usaha yang direncanakan dan dilaksanakan dengan baik melalui suatu proses yang berkelanjutan.Salah satu upaya yang dilakukan untuk meningkatkan mutu pendidikan di madrasah khususnya, yaitu melalui implementasi $^{1}$ Manajemen Berbasis Madrasah (MBM) yang dalam

1Implementasi adalah "proses untuk melaksanakan ide, program atau seperangkat aktivitas baru dengan harapan orang lain dapat menerima dan melakukan perubahan".Pendapat lain mendefinisikan implementasi adalah proses perubahan perilaku, suatu upaya memperbaiki 
pelaksanaannya di Indonesia digunakan Istilah Manajemen Peningkatan Mutu Berbasis Madrasah (MPMBM). Sebagaimana yang dikemukakan Sagala ${ }^{2}$ bahwa "Sistem manajemen berbasis madrasah sebagai wujud reformasi pendidikan dimaksudkan untuk meningkatkan mutu madrasah." Usman ${ }^{3}$ juga menyatakan bahwa "untuk meningkatkan mutu madrasah, sejak tahun 2001, madrasahmadrasah negeri di Indonesia telah mulai menerapkan Manajemen Berbasis Madrasah."

Mencapai mutu pendidikan madrasah, maka dalam penerapan Manajemen Berbasis Madrasah ini, madrasah diberikan otonomi ${ }^{4}$ untuk mengatur dan menyelenggarakan sistem pendidikannya, akan tetapi Manajemen Berbasis Madrasah tidak berarti membiarkan desentralisasi madrasah dan masyarakat menurut cara mereka sendiri, namun tetap mengacu kepada tujuan pendidikan nasional. Dengan Manajemen Berbasis Madrasah memberi kewenangan kepada madarsah untuk menentukan visi dan misi, menyusun perencanaan madrasah, membagi tugas kepada seluruh personal, kepala madrasah memimpin penyelenggaraan program madrasah, melakukan pengawasan dan perbaikan sesuai dengan keperluan. Sebagaimana yang dikemukakan Sufyarma ${ }^{5}$ bahwa "Kewenangan ini diharapkan madrasah dapat lebih mandiri dan mampu menentukan arah pengembangan yang sesuai dengan kondisi dan tuntutan lingkungan masyarakat."Sehingga lulusan madrasah benar-benar bermutu yang tidak hanya dari hasil pendidikan yang diperoleh akan tetapi juga bermutu sesuai dengan harapan masyarakat.

Istilah Manajemen Peningkatan Mutu Berbasis Madrasah (MPMBM) dipakai oleh Departemen Pendidikan Nasional Republik Indonesia untuk menyebut istilah lain dari Manajemen Berbasis Madrasah (MBM), yang secara umum diartikan sebagai model manajemen yang memberi otonomi lebih besar pada madrasah dan mendorong pengambilan keputusan partisipatif yang

pencapaian harapan-harapan yang terjadi secara bertahap, terus menerus, dan jka ada hambatan dapat ditanggulangi (Syafrudin, 2005: 72). Berdasarkan kedua pendapat di atas dapat dipahami bahwa yang dimaksud dengan implementasi adalah suatu kegiatan melaksanakan suatu ide atau program untuk mencapai tujuan.

2 Syaiful Sagala, Manajemen Strategik dalam Peningkatan Mutu Pendidikan.(Bandung: Alfabeta.2007). h.170

${ }_{3}$ Husaini Usman, Manajemen Teori, Praktik, dan Riset Pendidikan. (Jakarta: Bumi Aksara. 2006),h. 502

4 Ada enam istilah yang perlu dijelaskan berkenaan dengan Desentralisasi dan Otonomi Daerah, yaitu Desentralisasi, Dekosentrasi, Delegasi, Devolusi, Privatisasi, dan OtonomiRodenelli membedakan empat yang pertama, Desentralisasi adalah penyerahan otoritas pusat kepada daerah-daerah. Dekosentrasi adalah penyerahan tanggungjawab layanan sektor tertentu pada perwakilan pemerintah pusat di daerah.Delegasi adalah pengalihan tanggungjawab untuk membuat keputusan dan pengaturan pengelolaan layanan publik kepada pemerintah daerah.Devolusi adalah pemerintah pusat mengalihkan otoritas pembuatan keputusan dan implementasinya kepada daerah.Dua konsep lain yaitu, privatisasi merupakan pengalihan otoritas sektoral kepada usaha-usaha swasta. Otonomi merupakan arah balik dari desentralisasi.Desentralisasi berangkat dari otoritas pusat yang di serahkan ke daerah, sedangkan Otonomi berangkat dari pengakuan atas pusat (Jalal, 2011: 75).

${ }^{5}$ Sufyarma, Kapita Selekta Manajemen Pendidikan, (Bandung: Alfabeta. 2004),h. 87 
melibatkan secara langsung semua warga madrasah untuk meningkatkan mutu madrasah berdasarkan kebijakan pendidikan nasional.

Pengertian tersebut dapat diambil pengertian bahwa Manajemen Berbasis Madrasah mengandung dua hal penting yaitu pemberian otonomi madrasah dan pengambilan keputusan partisipatif. Menurut Nurkholis 6 yang dimaksud dengan otonomi madrasah adalah kewenangan madrasah untuk mengatur dan mengurus kepentingan warga madrasah menurut prakarsanya sendiri berdasarkan aspirasi warga madrasah dan sesuai dengan peraturan perundangan pendidikan nasional yang berlaku. Sedangkan pengambilan keputusan partisipatif maksudnya cara pengambilan keputusan dengan menciptakan lingkungan terbuka dan demokratik di mana warga madrasah didorong untuk terlibat secara langsung dalam proses pengambilan keputusan yang akan dapat berkontribusi terhadap pencapaian tujuan madrasah.

Jadi, dengan otonomi yang lebih besar maka madrasah memiliki kewenangan yang lebih besar dalam mengelola madrasahnya sehingga madrasah lebih mandiri. Dengan kemandiriannya madrasah lebih berdaya dalam mengembangkan program-program yang lebih sesuai dengan kebutuhan dan potensi yang dimiliki. Dengan pengambilan keputusan yang partisipatif maka rasa memiliki warga madrasah dapat meningkat. Meningkatnya rasa memiliki akan meningkatkan rasa tanggung jawab yang selanjutnya meningkatkan dedikasi warga madrasah terhadap madrasahnya. Dengan demikian dapat disimpulkan bahwa melalui pelaksanaan Manajemen Berbasis Madrasah berarti adanya peningkatan otonomi madrasah dan pengambilan keputusan partisipatif ditujukan untuk meningkatkan mutu pendidikan madrasah.

Menurut pendapat Slamet ${ }^{7}$, bahwa Manajemen Berbasis Madrasah bertujuan untuk memberdayakan madrasah, terutama sumber daya manusia melalui pemberian kewenangan, fleksibilitas sumber daya lain untuk memecahkan persoalan yang dihadapi oleh madrasah yang bersangkutan. Menurut Subakir8 tujuan utama penerapan Manajemen Berbasis Madrasah adalah untuk meningkatkan efisiensi pengelolaan dan meningkatkan relevansi pendidikan di madrasah, dengan adanya wewenang yang lebih besar dan lebih luas bagi marasah untuk mengelola urusannya sendiri. Mulyasa9lebih memperinci lagi bahwa tujuan dilaksanakan atau diterapkannya Manajemen Berbasis Madrasah di Indonesia adalah; (1) Peningkatan efisiensi, antara lain diperoleh melalui keleluasaan mengelola sumberdaya partisipasi masyarakat dan penyederhanaan birokrasi. (2) Peningkatan mutu, antara lain melalui

${ }^{6}$ Nurkholis. Manajemen Berbasis Sekolah, (Jakarta: Grasindo,2003), h.9

7 Slamet P.H. Manajemen Berbasis Sekolah, Jurnal Pendidikan dan Kebudayaan, Volume 2 Nomor 7, 2001), h.1

8 Supriono Subakir dan Achmad Sapari,Manajemen Berbasis Sekolah, (Surabaya: Penerbit SIC, 2001), h. 5

${ }^{9}$ E. Mulyasa, Manajemen Berbasis Sekolah, (Bandung: Remaja Rosdakarya, 2003), h.25 
partisipasi orangtua terhadap sekolah, fleksibilitas pengelolaan sekolah dan kelas, peningkatan profesionalisme guru dan kepala sekolah. (3) Peningkatan pemerataan, antara lain diperoleh melalui peningkatan partisipasi masyarakat yang memungkinkan pemerintah lebih berkonsentrasi pada kelompok tertentu.

Dengan demikian Manajemen Berbasis Madrasah memiliki tujuan utama yaitu untuk meningkatkan kualitas pendidikan di madrasah. Dengan konsep Manajemen Berbasis Madrasah ini memberikan kemandirian dan kreativitas pada madrasah, seperti dalam mengelola sumber daya dan menggunakannya sesuai dengan kebutuhan, menyertakan masyarakat untuk berpartisipasi, mendorong profesionalisme kepala madrasah dan para guru, mendorong guru kreatif, dan menyusun program pembelajaran yang sesuai dengan kebutuhan siswa, sehingga dapat meningkatkan prestasi belajar siswanya. Dengan demikian tujuan penerapan Manajemen Berbasis Madrasah dapat disimpulkan adalah untuk meningkatkan kualitas pendidikan secara umum baik itu menyangkut kualitas pembelajaran, kualitas kurikulum, kualitas sumber daya manusia dan kualitas pelayanan pendidikan.

Keberhasilan dalam mengimplementasikan Manajemen Berbasis Madrasah, diantaranya adalah meningkatnya kedisiplinan guru. Guru merupakan tokoh sentral dalam pelaksanaan Manajemen Berbasis Madrasah yang diimplementasikan dalam kegiatan pembelajarannya. Oleh karena itu guru yang memiliki tingkat kedisiplinan yang tinggi yang akan mampu mengimplementasikan Manajemen Berbasis Madrasah dengan baik. Sebagaimana yang dikemukakan Usman ${ }^{10}$ salah satu prinsip yang harus dipahami dan ada ketika akan melaksanakan Manajemen Berbasis Madrasahadalah kesiapan dari guru dalam melaksanakan Manajemen Berbasis Madrasah tersebut.

Kedisiplinan merupakan salah satu sikap yang sangat penting dalam menjalankan tugas profesi. Penelitian Eko Susilo dalam Sagala11 menggambarkan bahwa kedisiplinan merupakan salah satu yang menonjol dari madrasah. Banyak orangtua peserta didik, menyekolahkan anaknya, selain faktor kualitas, motivasi utamanya adalah kedisiplinan.Untuk itu setiap unsur dalam lingkungan madrasah haruslah melaksanakan kedisiplinan dengan baik, karena merupakan cerminan keefektifan kegiatan dalam madrasah tersebut. Starawaji ${ }^{12}$ menyatakan bahwa "sebagus apapun lembaga pendidikan atau sepintar apapun pendidik, jika tanpa disiplin dalam melaksanakan tugasnya, tujuan pendidikan tidak akan tercapai dengan maksimal."

Menurut Imron ${ }^{13}$ pengertian disiplin adalah "suatu keadaan tertib di mana orang-orang yang tergabung dalam suatu organisasi tunduk pada peraturan-

\footnotetext{
${ }^{10}$ Husaini Usman, Manajemen Teori, Praktik...,h.496

11 Syaiful Sagala, Manajemen Strategik dalam...,h.205

12Starawaji. Kedisplinan Guru, dalam http://www.starawaji.wordpress.com/, 10 Juni 2011

${ }^{13}$ Ali Imron, Manajemen Peserta Didik Berbasis Sekolah, (Jakarta: Bumi Aksara. 2011),h.172
} 
peraturan yang telah ada dengan rasa senang hati." Rusyan ${ }^{14}$ mendefinisikan disiplin adalah "suatu perbuatan yang mentaati, mematuhi tata tertib akan aturan, norma dan kaidah-kaidah yang berlaku baik di masyarakat maupun di tempat kerja. Gordon ${ }^{15}$ mengatakan disiplin dipahami sebagai perilaku dan tata tertib yang sesuai dengan peraturan dan ketetapan atau perilaku yang diperoleh dari pelatihan, seperti misalnya disiplin dalam kelas atau disiplin sebuah tim bola basket yang baik

Berdasarkan beberapa pendapat tersebut dipahami bahwa yang kedisiplinan guru adalah suatu keadaan tertib dan teratur yang dimiliki guru di madrasah terhadap segala peraturan yang ada dengan rasa senang hati, tanpa ada pelanggaran-pelanggaran yang merugikan baik secara langsung maupun tidak langsung terhadap guru sendiri dan terhadap madrasah secara keseluruhan. Menurut Starawaji Guru yang disiplin apabila memiliki ciri-ciri sebagai berikut: 1) patuh terhadap aturan madrasah, 2) mengindahkan petunjukpetunjuk yang berlaku di madrasah, 3) rajin dalam mengajar, 4) tepat waktu dalam mengajar, 5) tidak pernah keluar saat mengajar, 5) tidak pernah membolos saat ada jadwal mengajar.

Banyak faktor yang dapat mempengaruhi kedisiplinan guru, salah satunya adalah implementasi Manajemen Berbasis Madrasah. Dengan demikian dipahami bahwa implementasi Manajemen Berbasis Madrasah akan berpengaruh terhadap kedisiplinan guru. Semakin baik implementasi Manajemen Berbasis Madrasah, maka akan semakin meningkat kedisiplinan guru.

Hasil prasurvey peneliti di MIN Kota Bandar Lampung terhadap kedisiplinan guru di MIN Kota Bandar Lampung adalah sebagai berikut: guru langsung masuk ke dalam kelas ketika jam pergantian jam berbunyi, ketika ada tugas piket guru datang lebih awal, guru tidak pernah bolos mengajar, selalu tepat waktu mengumpulkan nilai hasil evaluasi, mengikuti rapat dewan guru, dan pulang pada waktunya.Hasil prasurvey terhadap implementasi Manajemen Berbasis Madrasah di MIN Kota Bandar Lampung adalah sebagai berikut: 1) masih kurangnya partisipasi masyarakat/orangtua dalam menentukan kebijakan dan perkembangan madrasah, 2) masih banyak guru yang tidak melaksanakan konsep MBM dalam kegiatan pembelajaran yaitu mengembangkan tujuan, materi, kegiatan, dan evaluasi yang sesuai dengan keadaan siswa, 3) kurangnya komunikasi yang baik antar unsur madrasah, 4) penyusunan RPP kurang memperhatikan kebutuhan siswa, 5) guru kurang terlibat dalam perencanaan perkembangan madrasah, 6) guru kurang berkomunikasi baik dengan orangtua siswa.

14 A.Rusyan, Tabrani, dkk. Upaya Meningkatkan Budaya Kinerja Guru Sekolah Dasar,(Jakarta: Inti Media Cipta Nusantara, 2001), h.54

15 Thomas Gordon, Menggajar Anak Berdisiplin diri, (Jakarta : PT Gramedia Pustaka Utama, 1996),h.3 
Berdasarkan hasil prasurvey tersebut timbul suatu permasalahan yaitu peningkatan kedisiplinan guru tidak ada hubungannya dengan implementasi Manajemen Berbasis Madrasah. Untuk itulah peneliti tertarik meneliti tentang "Pengaruh Implementasi Manajemen Berbasis Madrasah terhadap kedisiplinan guru di MIN Kota Bandar Lampung," dengan rumusan masalah "Sebarapa besar pengaruh yang signifikan implementasi Manajemen Berbasis Madrasah terhadap kedisiplinan guru di MIN Kota Bandar Lampung?". Sehingga tujuan dalam penelitian ini adalah untuk mengetahui pengaruh implementasi Manajemen Berbasis Madrasah terhadap kedisiplinan guru di MIN Kota Bandar Lampung.Melalui penelitian ini diharapkan berguna bagi pengembangan ilmu pengetahuan khususnya dalam manajemen pendidikan Islam tentang implementasi Manajemen Berbasisi Madrasah dan pengaruhnya terhadap kedisiplinan guru. Selain itu secara teoritis akan menambah kajian keilmuan dalam pendidikan Islam. Selain itu menambah wawasan para pengelola pendidikan di madrasah tentang pentingnya upaya meningkatkan implementasi Manajemen Berbasis Madrasah, sehingga kedisiplinan guru akan semakin meningkat dengan optimal.

\section{Metode Penelitian}

Penelitian ini menggunakan jenis penelitian kuantitatifyang dimulai dengan berpikir deduktif untuk menurunkan hipotesis, kemudian melakukan pengujian di lapangan, kesimpulan atau hipotesis tersebut ditarik berdasarkan data empiris.Sampel pada penelitian ini adalah 26 orang guru MIN Kota Bandar Lampung.Teknik pengumpulan data yang digunakan adalah kuesioner. Kuesioner diberikan kepada guru MIN Kota Bandar Lampung untuk mengetahui implementasi Manajemen Berbasis Madrasahdan kedisiplinan guru.Teknik analisis data menggunakan teknik korelasi sederhana.Analisis korelasi sederhana digunakan untuk menelaah pengaruh antara dua variabel.Pengujian keberartian dengan kriteria yang digunakan adalah apabila nilai $r$ lebih besar dari nilai $\alpha$ tertentu maka Ho diterima. Sebaliknya apabila nilai $\mathrm{r}$ lebih kecil dari $(<)$ nilai $\alpha$ tertentu maka Ho ditolak.

\section{Hasil Penelitian}

Data yang dikumpulkan mengenai implementasi Manajemen Berbasis Madrasah diperoleh melalui penyebaran kuesioner sebanyak 34 item soal yang diberikan kepada 26 orang guru di MIN Kota Bandar Lampung. Berikut hasil analisis data skor responden penelitian tentang implementasi Manajemen Berbasis Madrasah di MIN Kota Bandar Lampung: 
Tabel 1

Deskripsi Data Implementasi

Manajemen Berbasis Madrasah

\begin{tabular}{|l|l|}
\hline Responden & 26 \\
\hline Rata-Rata & 72.12 \\
\hline Nilai Tengah & 70.50 \\
\hline Nilai yang Sering Muncul & 68 \\
\hline Nilai Terendah & 49 \\
\hline Nilai Tertinggi & 95 \\
\hline Jumlah & 1875 \\
\hline
\end{tabular}

Sumber: Pengolahan data dengan SPSS

Tabel di atas diketahui bahwa nilai rata-rata yang diperoleh responden penelitian yang menjawab kuesioner penelitian tentang implementasi Manajemen Berbasis Madrasah di MIN Kota Bandar Lampung sebesar 72,12. Nilai tertinggi yang diperoleh responden 95 dan nilai yang terendah yaitu 49 . Persentase pencapaian responden penelitian tentang implementasi Manajemen Berbasis Madrasah di MIN Kota Bandar Lampungsebesar 70,7\%. Berdasarkan pengkatagorian di atas dapat diinterpretasikan bahwa implementasi Manajemen Berbasis Madrasah di MIN Kota Bandar Lampung dikatagorikan cukup baik.

Data yang dikumpulkan mengenai kedisiplinan guru di MIN Kota Bandar Lampung diperoleh melalui penyebaran kuesioner sebanyak 21 item soal yang diberikan kepada 26 orang guru di MIN Kota Bandar Lampung.Berikut hasil analisis data skor responden penelitian tentang kedisiplinan guru di MIN Kota Bandar Lampung:

Tabel 2

Deskripsi Data Kedisiplinan Guru

\begin{tabular}{|l|l|}
\hline Responden & 26 \\
\hline Rata-Rata & 42.12 \\
\hline Nilai Tengah & 42.50 \\
\hline Nilai yang Sering Muncul & $42^{\mathrm{a}}$ \\
\hline Nilai Terendah & 29 \\
\hline Nilai Tertinggi & 54 \\
\hline Jumlah & 1095 \\
\hline Sumber: Pengolahan data dengan SPSS &
\end{tabular}

Berdasarkan tabel di atas diketahui bahwa nilai rata-rata yang diperoleh responden penelitian yang menjawab kuesioner penelitian tentang kedisiplinan guru Pendidikan Agama Islam di MIN Kota Bandar Lampung sebesar 42,12. Nilai tertinggi yang diperoleh responden 54 dan nilai yang terendah yaitu 29.Persentase pencapaian responden penelitian tentang kedisiplinan guru di MIN Kota Bandar Lampungsebesar 66,8\%. Berdasarkan pengkatagorian di atas 
dapat diinterpretasikan bahwa kedisiplinan guru di MIN Kota Bandar Lampung dikatagorikan cukup baik.

Hipotesis yang akan diuji kebenarannya dalam penelitian ini adalah "Semakin baik implementasi Manajemen Berbasis Madrasah maka akan semakin meningkat kedisiplinan guru di MIN Kota Bandar Lampung". Untuk menguji hipotesis keduatersebut, peneliti menggunakan uji statistik korelasi sederhana. Berikut hasil uji korelasinya:

Tabel 3

Hasil Analisis Korelasi Implementasi Manajemen

Berbasis Madrasahdengan Kedisiplinan Guru

\begin{tabular}{|l|l|l|l|}
\hline \multicolumn{2}{|l|}{} & $\begin{array}{l}\text { Implementasi } \\
\text { Manajemen Berbasis } \\
\text { Madrasah }\end{array}$ & $\begin{array}{l}\text { Kedisiplinan } \\
\text { Guru }\end{array}$ \\
\hline $\begin{array}{l}\text { Implementasi } \\
\text { Manajemen Berbasis } \\
\text { Madrasah }\end{array}$ & Pearson Correlation & 1 & $.690^{* *}$ \\
\cline { 2 - 4 } & Sig. (2-tailed) & & .000 \\
\cline { 2 - 4 } & $\mathrm{N}$ & 26 & 26 \\
\hline Kedisiplinan Guru & Pearson Correlation & $.690^{* *}$ & 1 \\
\cline { 2 - 4 } & Sig. (2-tailed) & .000 & 26 \\
\cline { 2 - 4 } & $\mathrm{N}$ & 26 & \\
\hline
\end{tabular}

Sumber: Pengolahan data dengan SPSS

Tabel di atas, menunjukkan bahwa koefisen korelasi variabel implementasi Manajemen Berbasis Madrasah dengan kedisiplinan guru di MIN Kota Bandar Lampung sebesar 0,690.Berdasarkan kategori tingkat keeratan hubungan, maka nilai koefisien korelasi variabel implementasi Manajemen Berbasis Madrasah dengan kedisiplinan guru di MIN Kota Bandar Lampung dikategorikan pengaruhnya cukup/sedang.Dengan demikian dapat disimpulkan bahwa implementasi Manajemen Berbasis Madrasah dengan kedisiplinan guru di MIN Kota Bandar Lampung memiliki pengaruh yang kuat/tinggi.

Besar kecilnya koefisien korelasi yang telah dihitung kuat lemahnya tingkat keeratan pengaruh antara variabel implementasi Manajemen Berbasis Madrasah dengan kedisiplinan guru di MIN Kota Bandar Lampung tidak memiliki arti apapun apabila belum dilakukan pengujian terhadap koefisien korelasi yang sudah dihitung. Pengujian keberartian koefisien korelasi dengan kriteria yang digunakan adalah apabila nilai $\mathrm{r}$ lebih kecil dari $(<)$ nilai $\alpha$ tertentu maka Ho ditolak, artinya terdapat pengaruh yang berarti/signifikan antara implementasi Manajemen Berbasis Madrasah dengan kedisiplinan guru di MIN Kota Bandar Lampung.Berdasarkan hasil perhitungan korelasi dapat diketahui nilai keberartian koefisien korelasi, yaitu nilai $\mathrm{r}$ lebih kecil dari pada tingkat $\alpha$ yang digunakan (yaitu 0,05) atau $0,000<0,05$, sehingga Ho ditolak. Artinya 
terdapat pengaruh yang berarti/signifikan antara implementasi Manajemen Berbasis Madrasah dengan kedisiplinan guru di MIN Kota Bandar Lampung. Untuk menggambarkan adanya pengaruh antara implementasi Manajemen Berbasis Madrasah dengan kedisiplinan guru di MIN Kota Bandar Lampung dapat dilihat pada gambar di bawah ini:

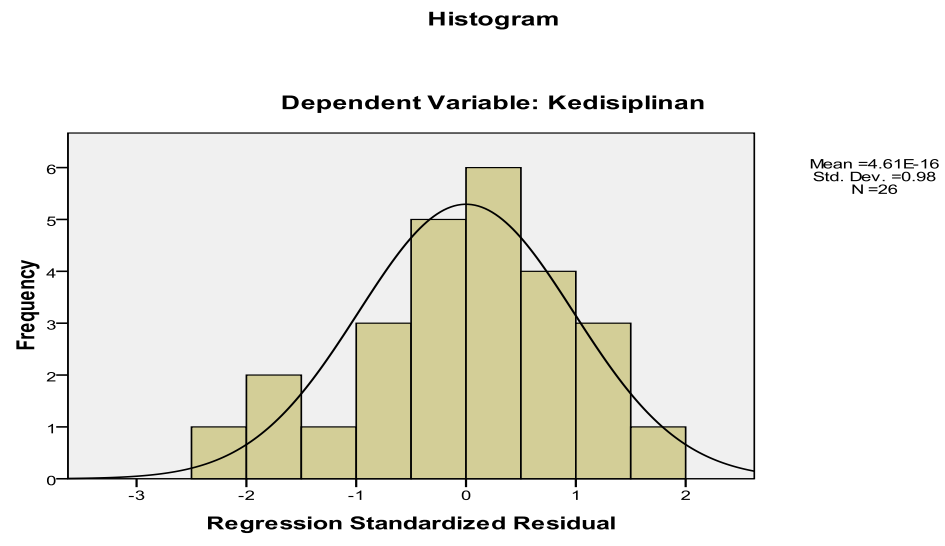

Gambar 3. Histogram Pengaruh Implementasi Manajemen Berbasis Madrasah terhadap Kedisiplinan Guru

Berdasarkan uraian hasil analisis datadiperoleh temuan bahwa terdapat pengaruh yang signifikan antara implementasi Manajemen Berbasis Madrasah dengan kedisiplinan guru di MIN Kota Bandar Lampung dengan kekuatan pengaruh sebesar 0,829. Hal ini berarti semakin baik implementasi Manajemen Berbasis Madrasah maka akan semakin meningkat kedisiplinan guru di MIN Kota Bandar Lampung. Dengan demikian berdasarkan uji statistik korelasi sederhana, ternyata hipotesis dalam penelitian ini diterima yaitu "Semakin baik implementasi Manajemen Berbasis Madrasah maka akan semakin meningkat kedisiplinan guru di MIN Kota Bandar Lampung."

Hasil penelitian ini sesuai dengan hasil penelitian Eko Susilo dalam Sagala $^{16}$ menggambarkan bahwa kedisiplinan merupakan salah satu yang menonjol dari madrasah. Banyak orangtua peserta didik, menyekolahkan anaknya, selain faktor kualitas, motivasi utamanya adalah kedisiplinan.Untuk itu setiap unsur dalam lingkungan madrasah haruslah melaksanakan kedisiplinan dengan baik, karena merupakan cerminan keefektifan kegiatan dalam madrasah tersebut. Starawaji menyatakan bahwa "sebagus apapun lembaga pendidikan atau sepintar apapun pendidik, jika tanpa disiplin dalam melaksanakan tugasnya, tujuan pendidikan tidak akan tercapai dengan maksimal."

Berdasarkan hasil penelitian dan pendapat tersebut dipahami bahwa melalui implementasi Manajemen Berbasis Madrasah, akan dapat meningkatkan kedisiplinan guru. Hal ini dikarenakan, untuk melaksanakan Manajemen Berbasis Madrasah dengan optimal memerlukan guru yang memiliki

16 Syaiful Sagala, Manajemen Strategik dalam...,h.205 
kedisiplinan kerja yang tinggi. Dengan demikian secara langsung implementasi Manajemen Berbasis Madrasah akan semakin memupuk kedisiplinan kerja dalam diri guru.

\section{Simpulan}

Kesimpulan dari hasil penelitian tersebut adalah sebagai berikut: Semakin baik implementasi Manajemen Berbasis Madrasah maka akan semakin meningkat kedisiplinan guru di MIN Kota Bandar Lampung. Kekuatan pengaruh implementasi Manajemen Berbasis Madrasah terhadap kedisiplinan guru di MIN Kota Bandar Lampung sebesar 0,690 yang dikategorikan pengaruhnya cukup/sedang.

Berdasarkan kesimpulan tersebut, maka diberikan rekomendasi sebagai berikut; (1) Kepada Kementerian Agama Wilayah Provinsi Lampung dan Kota Bandar Lampung, untuk memberikan pelatihan pada kepala madrasah, guru maupun staff TU untuk lebih memahami tentang Manajemen Berbasis Madrasah. Karena Manajemen Berbasis Madrasah akan dapat diimplmentasikan dengan lebih baik apabila, segenap unsur madrasah memahami Manajemen Berbasis Madrasah itu sendiri. (2) Kepada kepala madrasah untuk selalu memperluas pengetahuan dan keterampilan gurunya dalam mengimplementasikan Manajemen Berbasis Madrasah dengan benar, karena akan berpengaruh pada peningkatan kedisiplinan guru tersebut. (3) Kepada para dewan guru untuk selalu meningkatkan pemahamannya tentang implementasi Manajemen Berbasis Madrasah, agar kedisiplinan semakin meningkat pula.

\section{Referensi}

A.Rusyan, Tabrani, dkk. Upaya Meningkatkan Budaya Kinerja Guru Sekolah Dasar. Jakarta: Inti Media Cipta Nusantara, 2001

Ali Imron, Manajemen Peserta Didik Berbasis Sekolah, Jakarta: Bumi Aksara. 2011

Depdiknas. Manajemen Peningkatan Mutu Berbasis Sekolah: Buku I Konsep dan Pelaksanaan. Jakarta: Direktorat SLP Dirjen Dikdasmen Sepdiknas. 2001

Depdiknas. Manajemen Peningkatan Mutu Berbasis Sekolah: Buku I Konsep dan Pelaksanaan. Jakarta: Direktorat SLP Dirjen Dikdasmen Sepdiknas. 2001

E. Mulyasa, Manajemen Berbasis Sekolah. Bandung: Remaja Rosdakarya, 2003

Husaini Usman, Manajemen Teori, Praktik, dan Riset Pendidikan. Jakarta: Bumi Aksara. 2006

Jalal, Fasli dan Supriadi,Dedi. Reformasi Pendidikan Dalam Konteks Otonomi Daerah. Yogyakarta: Adicita karya Nusa, 2001

Nurkholis. Manajemen Berbasis Sekolah. Jakarta: Grasindo,2003

Slamet P.H. Manajemen Berbasis Sekolah, Jurnal Pendidikan dan Kebudayaan, Volume 2 Nomor 7. 2001

Starawaji. Kedisplinan Guru, dalam http://www.starawaji.wordpress.com/, 10 Juni 2011

Sufyarma, Kapita Selekta Manajemen Pendidikan. Bandung: Alfabeta. 2004 
Supriono Subakir dan Achmad Sapari,Manajemen Berbasis Sekolah. Surabaya: Penerbit SIC, 2001

Syafruddin. Guru Profesional dan Implementasi Kurikulum, Jakarta; Quantum Teaching. 2005

Syaiful Sagala, Manajemen Strategik dalam Peningkatan Mutu Pendidikan. Bandung: Alfabeta 2007

Thomas Gordon, Menggajar Anak Berdisiplin diri. Jakarta : PT Gramedia Pustaka Utama, 1996 